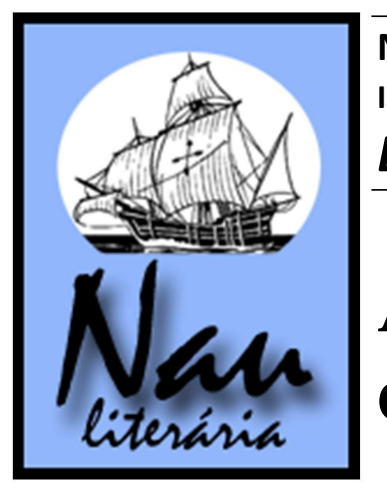

\title{
A busca da origem em Natália, de Helder Macedo
}

\section{Bruna da Silva Nunes*}

Resumo: Este artigo trata da busca da origem no livro Natália, de Helder Macedo, pela narradora/protagonista que dá título à obra. Para isso, ele se fundamenta em teorias da psicanálise que trabalham com a temática da importância do olhar materno.

Palavras-chave: Origem; busca; mãe; olhar; família.
Resumen: Este artículo trata de la búsqueda del origen en el libro Natália, de Helder Macedo, por la narradora/protagonista que da el título a la obra. Para eso, el artículo se basa en las teorías del psicoanálisis que trabajan con el tema de la importancia de la mirada materna.

Palavras-clave: Origen; busca; madre; mirar; família.

Há sempre algo de ausente que me atormenta

Camille Claudel

O conhecimento da origem é intrínseco a nossa existência: todos nós queremos saber de onde viemos, porque estamos aqui. Essa preocupação é observada desde a teoria da origem do universo até, por exemplo, nas pessoas adotadas que procuram por seus pais biológicos. Ao mesmo tempo, só este saber não basta, ele necessita de legitimação: o olhar da figura materna. $\mathrm{O}$ encontro precoce entre o bebe e a mãe estabeleceria nossa capacidade de ser, porque, segundo Winnicott, o rosto da mãe teria uma função de espelho. "Quando olho, sou visto; logo, existo." Sobre esta troca de olhares estruturante, ele descreve:

O que o bebe vê quando olha o rosto da mãe? Sugiro que, normalmente, o que o bebe vê é ele mesmo. [...] Muitos bebes, contudo, tem uma longa experiência de não receber de volta o que estão dando. Eles olham e não veem a si mesmos [...] Procuram outros meios de obter algo de si mesmo de volta, a partir do ambiente. (WINNICOTT, 1975, apud MOURA; OUTEIRAL, 2002, p. 7)

A falta desse olhar, seja por ausência física ou de vinculo, é tida como responsável por alguns problemas na vida adulta, descrito por Anna Freud (1958) num outro contexto: "algum mal sutil esta sendo infligido à criança, e que suas consequências se manifestarão em data futura'.” (FREUD, 1958, apud MOURA; OUTEIRAL, 2002, p. 9)

\footnotetext{
* Graduanda em Letras (UFRGS).
} 
Segundo A.Green (1988), o complexo da mãe morta, que acontece quando por algum motivo a mãe não consegue ser o espelho do bebê, provoca uma morte parcial, fazendo com que ele desvie seu olhar para um terceiro mas, dificilmente, terá suas aflições respondidas, seja por este objeto não estar disponível ou por não compreender a criança. Essa nova frustação pode desencadear no bebê um processo de masculinização, associado ao fazer, dissociado de uma capacidade de ser.

Em Natália, a inexistência do olhar materno norteou as ações da protagonista. Seu trabalho, o de entrevistadora em um canal de televisão, demonstra sua necessidade de ser olhada, pois a colocava em uma posição de ser vista por muitas pessoas, assim como sua vontade de ser escritora: "Buscas compensatórias de se constituir a partir do olhar do outro podem se manifestar durante toda vida [...] como numa exposição de si próprio em criações artísticas a serem admiradas por diversos observadores." (MOURA; OUTEIRAL, 2002, p. 8).

A narradora não possuía um conhecimento totalizante sobre sua origem, os pais haviam sido assassinados quando Natália era recém-nascida, e seu principal elo com o passado era o avô materno, que lhe contava histórias sobre seus pais e seu nascimento, mas de uma maneira fragmentada e metafórica, enquanto sua avó: “às vezes ficava a escutar pela porta entreaberta a suspirar.” (MACEDO, 2010, p. 24). E sobre a relação da avó com o avô: "sempre tinha deixado para ele as iniciativas. E depois, seguia-o como podia." (MACEDO, 2010, p. 53) Como Natália narra, isso faz com que sua vida seja uma "história de fantasmas":

Tinha começado assim: 'a morte foi o inicio de outra vida.' E depois, como achei horrivelmente literário, acrescentei: 'Não para os que morreram, é claro, esses já não têm nada a ver com isso.' O que eu de fato acho e que não tinha escrito é que se calhar foi mesmo para não terem nada a ver com isso que lhes serviu morrerem. Mas também acho que as vidas dos mortos se podem tornar noutra vida para aqueles que se metem na vida deles. Como para mim agora, enquanto espero que também chegue a minha vez de já não ter nada a ver com isso. Sou nova, talvez tenha de esperar ainda muito tempo. A questão é que enquanto espero não consigo deixa-los em paz. Ou eles a mim, tornando a minha vida numa história de fantasmas em que o fantasma sou eu. A viver num presente que não reconhece o seu passado. A ter de imaginar semelhanças para poder presumir diferenças. (MACEDO, 2010, p.10)

Por ser o avô quem lhe fornecia informações sobre os pais, havia uma relação de dependência de Natália para com ele, e muitos de seus atos serão pautados com o objetivo de agradar ou não o avô, muitas vezes mostrando falta de personalidade. Um exemplo foi seu casamento com Paulo, homem que ela não amava, mas que era muito admirado por seu avô, como a narradora explica:

Raras vezes tínhamos visitas em casa. A principal exceção era Paulo, que foi aluno e depois assistente dele na universidade e com quem me vim a casar. Creio que na altura pensei que era o que o avô tinha querido que eu fizesse, mas foi um grande engano. Ou então, não foi isso que eu pensei, se calhar até pensei o contrário e foi por isso que eu casei. (MACEDO, 2010, p. 28) 
Outra amostra foi seu relacionamento com Jorge, primo de Paulo. Parece-me que ela ficou com ele para contrariar o avô, pois ela pensava que ele não gostava do novo companheiro; assim que o avô morreu, separou-se de Jorge.

Após a morte dos avós, a narradora parte em busca de sua identidade, porque agora não possuía mais família, ninguém em quem se espelhar. Nesta procura, Natália descobre novos fatos sobre a morte dos pais e percebe que tudo que sempre acreditou podia ser mentira e que ela poderia não ser quem achava que era. Neste momento de fragilidade, a protagonista conhece Fátima, mulher de Paulo, seu ex-marido. Ambas acabam por se envolver amorosamente, mas Fátima representa muito mais do que simplesmente um encontro físico: ela se torna a figura materna que Natália não teve. Inicialmente, isso é percebido quando Natália observa Fátima amamentar o filho. A narradora fica fascinada com a imagem, pois ela não passou pela experiência de ser alimentada por sua mãe:

A criança começou logo num berreiro. Ela tirou-o do berço, sossegou-o contra o peito, "pronto, pronto", e depois disse que devia estar com fome, se eu me importava que lhe desse de mamar. Fiquei a observar, discretamente, é claro, nunca tinha visto. Um seio a amamentar fica outra coisa, não é só pela função, mas, não sei como dizer, parece que adquire vida própria. Ou então não é bem isso, parece que fica a pertencer mais a boca do bebê e não ao peito da mãe [...] A visão de Fátima a amamentar não me sai da cabeça. Do seio muito branco, como um globo luminoso. Mas isso deve ser porque nunca tive mãe. (MACEDO, 2010, p. 107)

Depois, essa conexão de Fátima com a ideia de mãe se torna mais evidente. A própria Fátima percebe a necessidade de Natália ter uma mãe e se utiliza desse artifício:

"Ó minha bebê, não tenhas medo"[...] "Se tu fosse a minha bebê, então é que poderias ajudar. Se eu fosse tua mãezinha. Assim, deixa, vou-me já embora se não queres que eu seja. Ou então deixa-me ser. Não queres? Eu sei que tu queres...Vem aqui." Abriu o roupão, desnudou os seios. "Não, sem as mãos. Só teus lábios." O leite era tépido, da temperatura dos nossos corpos. Mais doce do que eu teria imaginado. De inicio saiu muito pouco. Depois, de repente, encheume a boca numa golfada. [...] O que eu senti, o que ouvi a voz dela dizer que eu estava a sentir, foi o peito dela articular-se com o meu, os nossos seios a intercalarem-se, depois os seios dela a descerem para o meu ventre, a deixarem um rastro úmido na minha pele, os dedos dela a separarem as minha pernas, a mão dela debaixo do meu dorso a levanta-lo, a expor as comissuras escondidas, os dedos dela a abrirem-me, a voz dela a dizer-me que aqueles meus lábios também queriam o seu leite, o seio dela a acariciar-me ali, os dedos dela a abrirem os lábios do meu ventre, a envolverem o bico do seu seio com as comissuras entreabertas, o leite dela a entrar em mim também ali, tomo o meu corpo a estremecer em ondas muito fundas, a sossegar e a estremecer de novo, a receber o leite que de novo entrava em mim. (MACEDO, 2010, p. 175-176)

A partir disso, o relacionamento das duas se torna ambíguo, pois, como a narradora descreve: "Éramos mulher e homem, mãe e filha..." (MACEDO, 2010, p.195). Fátima transformou-se na mãe idealizada, que tudo supre, passando a possuir um grande poder sobre ela, tomando o lugar do avô e tornando-se o alvo da dependência de Natália: "Não era só do meu presente que a Fátima se tinha apoderado, era também do meu passado. Ao tomar o lugar 
do meu avô em minha vida, tinha usurpado o lugar de seu maior rival. Tinha se tornado tudo e todos para mim." (MACEDO, 2010, p.198)

Na sua relação com Fátima, mais uma vez está presente a busca da legitimação de Natália, pois ela apenas transferiu a representação da figura de um para outro, com a vantagem de que, sendo mulher, Fátima satisfaria sua fome de mãe.

Fátima morre. Como ela era tudo, Natália sente-se sem nada, usurpada, incapaz de amar novamente. Não consegue ser sem ter um reflexo. De novo, deixa-se ser levada, aceitando a proposta de Paulo para casar de novo e criarem o filho dele com Fátima, numa construção "família patchwork", formada com retalhos do que sobrou de cada um "escolhidos conforme [...] e da imagem que se quer montar." (CORSO; CORSO, 2011, p. 216, 217 ) .

Agora, Natália parece-se com a avó, vivendo na sombra, deixando as decisões para os outros e "seguindo como pode": "Ontem, quando Diogo estava no escritório com ele, ouvi pela porta entreaberta a conversa deles." (MACEDO, 2010, p. 237).

\section{Referências}

MACEDO, Helder. Natália. Rio de Janeiro: Beco do Azougue, 2010.

MOURA, Luiza; OUTEIRAL, José. Paixão e Criatividade. 2. ed. Rio de Janeiro: Revinter, 2002.

CORSO, Diana L.; CORSO, Mário. A psicanálise na Terra do Nunca. Porto Alegre: Penso, 2011. 